I submit, Sir, that an antenatal screening programme of a general population has nothing to recommend it at this time, and that to advocate such a programme in the absence of a full discussion of the relevan issues, some of which I have touched upon here, is little short of irresponsible.-I am, etc.,

J. Philip Welch

Faculty of Medicine,

Department of Paediatrics,

Halifax, N.S., Canada

1 Screening in Medical Care, London, Oxford, University Press (for Nuffield Provincial Hos University Press
pitals Trust), 1968.

2 Welch, J. P. Lancet, 1970, 1, 722

3 Wilson, J. M. G., in Screening in Medical Care p. 97, London, Oxford University Press (for Nuffield Provincial Hospitals Trust), 1968.

Gerald, P. S., Pediatrics, 1967, 39, 325

Cunningham, G. C., California Medicine, 1966

Report by the Consultant Paediatricians and Medical Off'cers of Health of the South-east Scot$1968,1,674$.

\title{
Near Drowning
}

SIR,-Three days before the article "Drowning. Its Clinical Sequelae and Management" (18 April, p. 157) appeared, a severe case of near drowning was admitted to the Royal Air Force Hospital Ely. Some points in the management of our case may be of general interest, since despite the high national incidence of actual drowning - up to 1,500 per year-only few of our hospital staff have previously been involved with the treatment of severe near drowning.

The patient, a 7-year-old boy, fell from the bank of a gravel pit. $\mathrm{He}$ was found floating face down by his father who instituted mouth to mouth ventilation and external cardiac massage while his companion ran to alert the emergency ambulance service. Approximately 15 minutes later the patient arrived at the casualty department.

On arrival the patient was unconscious, deeply cyanosed, had inactive dilated pupils, occasional gasning recpiration, and an irregular bradycardia about $40 / \mathrm{min}$. The skin was extremely cold and pale. Shivering and intense muscle spasm, which produced opisthotonos and trismus, were present. Blood pressure was unrecordable. The upper airwav was cleared and the patient ventilated with $100 \%$ oxygen. The suxamethonium used to facilitate intubation made management much easier as opisthotonos stopped. On the assumption that the muscle spasm was due to cerebral oedema resulting from cardiac arrest it was decided to give $100 \mathrm{ml}$ of Urevert intravenously. While this was being given ampicillin $500 \mathrm{mg}$ and cloxacillin $500 \mathrm{mg}$ were given intramuscularly and hydrocortisone $100 \mathrm{mg}$ intravenously. Dextran-40 was given to counteract the profound shock.

The following investigations were then undertaken from femoral arterial puncture. Astrup results 45 minutes after near drowning were:

\section{$\mathrm{pH}$}

Actual $\mathrm{PCO}_{2}$

Base excess

Buffer base

Total $\mathrm{CO}_{2}$
$.0 \mathrm{mEq} / 1$. plasma

6.9

$120 \mathrm{~mm} \mathrm{Hg}$

$-21 \mathrm{mEq} / \mathrm{l}$. blood

$30 \mathrm{mEq} / 1$. blood

$23.0 \mathrm{mEq} / 1$. plasma

$26.6 \mathrm{mEq} / 1$. plasma

(Ventilated on $\left.100 \% \quad \mathrm{O}_{2}\right) \quad \mathrm{Po}_{2} 175 \mathrm{~mm} \mathbf{H g}$ $=99 \cdot 1 \%$ saturated.

Electrolytes: Sodium $114 \mathrm{mEq} / 1$. Potassium $7.4 \mathrm{mEq} / 1$. Chloride $82 \mathrm{mEq} / 1$.

While awaiting these results an infusion of sodium bicarbonate was started and ove the next four hours a total of $250 \mathrm{ml}$ of $4 \cdot 2 \%$ sodium bicarbonate and $350 \mathrm{ml}$ of Ringerlactate together with $500 \mathrm{ml}$ of recta Resonium "A" were given; this achieved correction to:

pH

Actual $\mathrm{PCO}_{2}$

$7 \cdot 22$

Base excess

$105 \mathrm{~mm} \mathrm{Hg}$

Buffer base

$+7 \mathrm{mEq} / 1$. blood

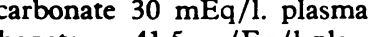

$\quad 41.5 \mathrm{~m} / \mathrm{Eq} / \mathrm{l}$.plasm

Total $\mathrm{CO}_{2}$

$44.6 \mathrm{mEq} / 1$. plasma

During this time the patient became restless and intolerant of his endotrachial tube, which was removed. Diazepam $4 \mathrm{mg}$ intravenously had excellent effect in quietening the patient. Consciousness was regained for the first time six and a half hours after the accident; during this time his mean axillary temperature was $97^{\circ} \mathrm{F}\left(36 \cdot 1^{\circ} \mathrm{C}\right)$.

Chest $x$-ray showed widespread patchy shadowing more marked on the right than left. All urine passed in the first twelve hours was examined for haemoglobin and none found. The following morning, sixteen hours after the accident, the patient ate his normal breakfast and was playing with toys $\mathrm{He}$ was discharged from hospital on the fourth day by which time chest $x$-ray showed considerable improvement in the shadowing.

It is interesting to note the patient's white blood count when seen in the outpatien department five weeks later. Total W.B.C.'s $8300 / \mathrm{mm}^{3}$ with $16 \%$ polymorph and $84 \%$ lymphocytes.

A case such as this at an inland hospital may take a casualty department by surprise and calls for enthusiastic resuscitation by a team, which in our case included surgeon, anaesthetist, and physician.-We are, etc.,

\section{Evans \\ C. PARSONS \\ J. HUNTON}

Royal Air Force Hospital

E!y, Cambs

\section{Clonidine in Treatment of Hypertension}

SIR,-We would like to comment on the work of Dr. A. I. Macdougall and others (22 August, p. 440) and that of Dr. A Amery and others (14 November, p. 392) and to compare it with our work on clonidine. Since our preliminary communication $^{1}$ a detailed report has been published. ${ }^{2}$ Our work on methyldopa and clonidine extended over a period of six months each, and we were able to study in 30 patients the side-effects, effectiveness, and tolerance of the two drugs. Unlike the experience with clonidine of Dr. Macdougall and colleagues who found that "side-effects from the drug were not disabling and were often transient" two of our patients developed such marked drowsiness that they refused to continue with clonidine. We feel that the greater number of side-effeats from clonidine compared with methyldopa which has been observed by Dr. Amery and colleagues and by us, should make the clinician prefer methyldopa to clonidine, as one of the main factors dissuading a hypertensive patient from continuing with his therapy is unwanted side-effects. Tolerance occurred in six of our patients on methyldopa and in seven patients on clonidine. Our average dosage was $916 \mathrm{mg}$ daily of methyldopa and $0.86 \mathrm{mg}$ daily of clonidine.

It seems a pity that Dr. Amery and colleagues used chlorthalidone in combination with both clonidine and methyldopa, as thiazides themselves may be effective hypotensive agents.-We are, etc.

Y. K. SEEDAT

E. I. VAWDA

S. MITHA

R. RAMASAR

Faculty of Medicine,

University of Natal,

See 'at, Y. K., Vawda, E. I., Mitha, S., and
Ramasar, R., Lancet, 1969, 2, 591 .
Seedat, Y. K., Vawda, E. I., Mitha, S., and
Ramasar, R., South African Medical fournal,
1970, 44, 300.

\section{Idiopathic Hypercalciuria}

SIR,-I read with interest the paper by Dr. Peter Adams and others 5 December p. 582). I should like to know whether the plasma potassium was estimated in the five patients who had a low serum inorganic phosphate during the control period. Hypokalaemia may be causally related to hypophosphataemia, ${ }^{1}$ and a fall in plasma phosphate can follow thiazide therapy, in some cases uninfluenced by potassium supplements. $^{2}$

I note that five patients had hypercalcaemia after phosphate deprivation, and a further three after the addition of chlorothiazide. How many, if any, of the initial five hypophosphataemic patients appeared in this hypercalcaemic group?I am, etc.,

ANTHONY J. RICHARDS

Clinical Pharmacology Unit,

Institute of Diseases of the Chest,

1 Anderson, D. C., Peters, T. J., and Stewart, W. K. British Merical fournal 196. fourna, J. R., and Nassim. R., British Medical

\section{Lactic Acidosis}

SIR,-We have recently seen a patient with biochemical findings similar to those reported by Dr. D. E. Barnardo and others (7 November, p. 348). However, our patient had diabetes mellitus and cirrhosis of the liver, and she was taking phenformin-all of which have been implicated as precipitating factors for lactic acidosis.

A 42-year-old female was admitted to hospital with a one-week history of malaise and a 24-hour history of progressive deterioration of conscious level. She had had diabetes mellitus for 18 years, treated recently with 20 units soluble insulin and 20 units P.Z.I. She was also receiving $50 \mathrm{mg}$ phenformin per day because of the unstable nature of har diabetes. One week prior to admission she had reduced her dose of insulin to six units P.Z.I. and four units of soluble because of hypoglycaemic reactions. She also had a three-year history of hepatosplenomegaly with biopsy cvidence of mild cirrhosis. On 